\title{
ARHGAP45 wt Allele
}

National Cancer Institute

\section{Source}

National Cancer Institute. ARHGAP45 wt Allele. NCI Thesaurus. Code C157545.

Human ARHGAP45 wild-type allele is located in the vicinity of 19p13.3 and is

approximately $22 \mathrm{~kb}$ in length. This allele, which encodes Rho GTPase-activating protein

45 , plays a role in the positive regulation of Rho family GT Pase activity. 